\title{
An improved rice transformation system using the biolistic method
}

\author{
Liangcai $\mathrm{Li}^{1}$, Rongda $\mathrm{Qu}^{2}$, Alexandre de Kochko ${ }^{2}$, Claude Fauquet ${ }^{2}$, and Roger N. Beachy ${ }^{2}$ \\ 1 Institute of Genetics. Academia Sinica, Beijing, China \\ 2 International Laboratory for Tropical Agricultural Biotechnology (ILTAB). Division of Plant Biology. Department of Cell Biology. \\ The Scripps Research Institute. La Jolla, CA 92037, USA
}

Received September 1, 1992/Revised version received December 22, 1992 - Communicated by G. C. Phillips

Abstract. Immature embryos and embryogenic calli of rice, both japonica and indica subspecies, were bombarded with tungsten particles coated with plasmid DNA that contained a gene encoding hygromycin phosphotransferase (HPH, conferring hygromycin resistance) driven by the CaMV $35 \mathrm{~S}$ promoter or Agrobacterium tumefaciens NOS promoter. Putatively transformed cell clusters were identified from the bombarded tissues 2 weeks after selection on hygromycin B. By separating these cell clusters from each other, and by stringent selection not only at the callus growth stage but also during regeneration and plantlet growth, the overall transformation and selection efficiencies were substantially improved over those previously reported. From the most responsive cultivar used in these studies, an average of one transgenic plant was produced from 1.3 immature embryos or from 5 pieces of embryogenic calli bombarded. Integration of the introduced gene into the plant genome, and inheritance to the offspring were demonstrated. By using this procedure, we have produced several hundred transgenic plants. The procedure described here provides a simple method for improving transformation and selection efficiencies in rice and may be applicable to other monocots.

Abbreviations: bp, base pairs; CaMV, cauliflower mosaic virus; GUS, $\beta$-glucuronidase; HPH, hygromycin phosphotransferase; hyg $\mathrm{B}$, hygromycin $\mathrm{B}$; hyg $\mathrm{g}^{\mathrm{I}}$, hygromycin resistance; NOS, Agrobacterium tumefaciens nopaline synthase; PCR, polymerase chain reaction; X-Gluc, 5-bromo-4chloro-3-indolyl- $\beta$ - $D$-glucuronide.

\section{Introduction}

The development of plant transformation techniques during the past decade has made it possible to improve crop plants by introduction of cloned genes. However, since the number of genes inserted and chromosomal locations of the integrated genes are not controllable, the expression of the introduced gene varies among individual transformants. Therefore, a relatively large number of transgenic plants must be developed in order to select desirable transformants as well as to study the expression of the introduced gene. For dicots, the Agrobacterium-mediated transformation system (Hooykaas, 1989) can be used to generate many transformants while for monocots, especially for the agronomically important cereal plants, current transformation systems still. need to be improved.

Transgenic cereal plants were first obtained in rice from protoplast transformation systems, with DNA uptake mediated by electroporation or/and polyethylene glycoi (PEG) (Toriyama et al. 1988; Zhang et al. 1988; Zhang and Wu, 1988; Shimamoto et al. 1989; Datta et al. 1990; Peng et al. 1992). However, since this method requires delicate manipulation of protoplasts as well as embryogenic suspension cell cultures, which are generally genotype-dependent, it is not readily applied to all cereal species. In the past few years, the biolistic method has emerged as a simple and promising alternative for cereal transformation, and has been successfully used in maize, rice, sugarcane and wheat transformation (Fromm et al. 1990; Gordon-Kamm et al. 1990; Christou et al. 1991; Bower and Birch, 1992; Vasil et al. 1992). Procedures using organized tissues such as immature embryos (Christou et al. 1991) or embryo slices (Cao et al. 1991) as target tissues for rice transformation may make the system less genotype-dependent. However, the reported transformation efficiency by the biolistic method is still low, and the probability of producing nontransformants (Christou et al. 1991) or chimeric plants (Cao et al. 1991) is high.

In our attempts to transform rice with coat protein genes of rice tungro bacilliform and spherical viruses (to be reported eisewhere), we have developed a procedure using the biolistic method to improve transformation and selection efficiencies and to reduce the numbers of non-transformants and chimeric rice plants. The target tissues used were immature embryos and embryogenic calli. The main differences between our procedure and those previously published include: the use of embryogenic rice calli, the excision of the hyg ${ }^{r}$ cell clusters at an early stage of selection, and the continuous selection on hyg $B$ during regeneration and plantlet growth. This procedure is simple. efficient, and may have general application in the iransformation of other monocor species by the biolistic method.

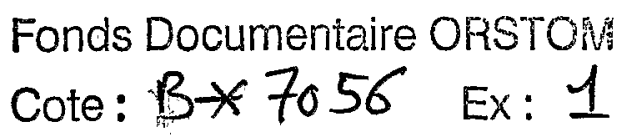




\section{Materials and Methods}

Materials The following rice (Oryza sativa, L.) varieties and lines were used: Taipei 309 (japonica), 77125 (japonica, bred by Dr. Shanbao Chen, Institute of Crop Cultivation and Breeding, Chinese Academy of Agricultural Sciences, Beijing, China), Tetep (indica), TN1 (indica) and 8706 (the latter is a stable line developed through anther culture of progeny of a cross between japonica and indica varieties, identified as morphologically intermediate but relatively indica-like. Line 8706 was bred by Dr. Ying Chen, the Institule of Genetics, Academia Sinica, Beijing, China). The target tissues used for bombardment were: (1) immature embryos dissected from immature seeds approximately 10-15 d after pollination. Tissue was placed on media with the scutellar side up for bombardment; (2) primary embryogenic calli induced from immature or mature embryos, or calli subcultured on solid medium for no longer than 3-4 months. All the seeds used in the experiments were dehulled and surfacesterilized according to Thompson et al. (1986).

Particle bombardment The particle gun employed in the experiments was a home-made apparatus, similar to that described by Klein et al. (1987), and the macroprojectile was driven by gun powder. Target explants, approximately $30-40$ immature embryos or $50-80$ pieces of calli (approximately $0.5 \mathrm{~cm}$ in size and total $2 \mathrm{~g}$ by weight), were centered on the medium in a Petri dish $10 \mathrm{~cm}$ in diameter. The plate was placed $8 \mathrm{~cm}$ beneath the stopping plate of the gun with a layer of metal net (120-180 mesh per linear inch) $1.5 \mathrm{~cm}$ above the target materials for even dispersion of tungsten particles. Plasmids used in the experiments included: pActlD which contains the rice actinl gene promoter linked to the GUS gene (McElroy et al. 1990; a gift from Dr. R. Wu); pNG3 which contains the NOS promoter driving HPH gene (a gift from Dr. M. C. Van Montagu); and pMON410 which contains CaMV $35 \mathrm{~S}$ promoter driving the $\mathrm{HPH}^{\prime}$ gene (Rogers et al. 1987; a gift from Monsanto Company). All plasmids were purified by $\mathrm{CsCl}$ gradient centrifugation. Coating of the tungsten particles (M10, Dupont, Wilmington, DE) was basically as described by Klein et al. (1988). In co-transformation experiments, $2.5 \mu \mathrm{g}$ of each plasmid was used in coating of approximately $40 \mu \mathrm{l}$ of particle suspension.

Two and one-half $\mu$ l of suspended panicles was loaded per shot; explants on each plate were bombarded twice.

Culture media The basic ingredients of the media included macroclements of N6 medium (Chu et al. 1975), microelements and vitamins of B5 medium (Gamborg et al. 1968), proline (500 mg/l), enzymatic cascin hydro lysate $(300 \mathrm{mg} / \mathrm{l})$, and sucrose $(30 \mathrm{~g} / \mathrm{l})$. The callus growth medium contained $2 \mathrm{mg} / \mathrm{l}$ of 2,4-D (2,4-dichlorophenoxyacetic acid). The regeneration medium contained $3 \mathrm{mg} / 1$ of BAP (6-benzylaminopurine). The same basal medium or MS medium (Murashige and Skoog, 1962) was used for plantlet growth without addition of phytohormones.

Growth and selection of transgenic tissues The bombarded materials and subsequent calli were cultured in the dark at $25^{\circ} \mathrm{C}$. Regencration and plantlet growth were carried out under $16 \mathrm{~h}$ photoperiod with light intensity of $110-130 \mu \mathrm{Mm}^{-2} \mathrm{~s}-1$ PAR using Sylvania F40/CW cool white fluorescent tubes. Hyg B (Calbiochem, La Jolla, CA) was added to the selection, regeneration, and plantlet growth media at the concentration of 30-50 $\mathrm{mg} / \mathrm{l}$. When well-grown plantlets reached $6-10 \mathrm{~cm}$, they were transplanted to soil and transferred to a greenhouse.

GUS assays Histochemical GUS expression (Jefferson et al. 1987) assays were performed basically as described by Klein et al. (1988). Methanol was added to a final concentration of $20 \%$ in the buffer to suppress endogenous $\beta$-glucuroniuase activity (Kosugi et al. 1990) Transient GUS expression assays were carried out $48 \mathrm{~h}$ after bombardment.

$P C R$ assays of the putative transgenic plants DNA samples of the putative transgenic rice plants were extracted from leaf or leaf sheath tissues based on McGarvey and Kaper (1991). PCR assays were performed in $50 \mu \mathrm{l}$ of each reaction with AmpliTaq DNA polymerase, Stoffel Fragment (Perkin Elmer Celus, Nonwalk, CT) according to the manufacturer's instruction. Two 18-mers (nt 236-253 of plus strand and nt 810-827 of minus strand) were designed as PCR primers based on the published sequence of the HPH gene (Gritz and Davies, 1983). A 592 bp amplified fragment of DNA was expected from transgenic plants. Ten $\mu l$ of each reaction was used for electrophoresis in a gel of $1 \%$ agarose (Gibco BRL, Gathersburg, MD) and TBE buffer (Sambrook et al. 1989).

Progeny test for resistance to hyg $B$ Seeds from self-pollinated hyg ${ }^{r}$ rice plants were dehulled and surface-sterilized as described above. They were germinated on MS medium without hormones but with the addition of 50 $\mathrm{mg} / \mathrm{l}$ of hyg $\mathrm{B}$, and incubated under conditions for plantlet growth as described above.

Southern analyses of transgenic plants Genomic DNA was extracted from leaf and stem tissues of rice plants based on Dellapora et al. (1983) with modifications. Five $\mu \mathrm{g}$ of genomic DNA from each sample, undigested or digested with restriction endonuclease (see relevant Figure Legends), was used for electrophoresis in an $0.8 \%$ agarose gel. DNA was blotted to Hybond-N nylon membrane (Amersham, Arlington Heights, IL) according to instructions of the manufacturer. Hybridization was carried out according to Church and Gilbert (1984). The HPH probe was a $1.1 \mathrm{~kb}$ Sma I fragment of pMON410 labeled by random hexamer priming with Klenow fragment of DNA polymerase 1 (Promega, Madison, WI) and 5'-[ $\alpha$ ${ }^{32}$ p jdATP (Amersham) based on the manufacturers' instructions .

\section{Results and Discussion}

\section{Transient GUS gene expression after bombardment}

After bombardment with tungsten particles coated with pAct1D, a high frequency of GUS expression was observed from both types of target materials (Fig. 1A, 1B). The average number of blue units per plate for each material were: $>750$ (for immature embryos) and $>1100$ (for calli), respectively (strain 77125). However, variation among different shots was high, e.g. from 176 to 2920 per plate for embryogenic calli, probably reflecting the variation in manipulation of the particle gun.

\section{Appearance and separation of hyg B-resistant cell clusters during early selection}

In a control experiment, we examined the effect of hyg $B$ on the growth of calli and regenerated plantlets from each of the rice varieties used. Callus growth was greatly inhibited when $30 \mathrm{mg} / \mathrm{l}$ of hyg B was added into the medium, and the growth was completely inhibited at a concentration of $50 \mathrm{mg} / \mathrm{l}$ (data not shown). Plantlets regenerated from nontransformed calli died when the medium contained $50 \mathrm{mg} / \mathrm{l}$ of hyg B. Based on these observations, the procedure for selecting stable transformants was designed.

One week after bombardment with the plasmid pMON410 or pNG3, immature embryos or embryogenic calli were transferred to selection medium containing 30 $\mathrm{mg} / \mathrm{l}$ of hyg B. The explants gradually turned brown. Two weeks later, fresh white cell clusters were identified on the surface of the bombarded tissues when viewed under a dissection microscope. Hyg ${ }^{\mathbf{r}}$ cell clusters which could be distinguished from each other (Figs. 1C, 1D) presumably originated from different transformation events. At this stage, the fresh cell clusters were carefully removed from the dying explant tissues and transferred to medium containing $30 \mathrm{mg} / \mathrm{l}$ of hyg $\mathrm{B}$ for further selection. Table $1 \mathrm{com}$ pares the yield of hyg ${ }^{I}$ cell clusters of two different types of explants from various rice varieties after bombardment with a plasmid containing HPH gene.

This table shows that hyg ${ }^{\mathrm{r}}$ cell clusters can be obtained from both immature embryos (1.7-2.7 clusters on average per embryo bombarded) and embryogenic calli (0.4-0.5 clusters per piece of callus bombarded). Not all the explants were responsive to the bombardment. Hyg $^{r}$ cell clusters 
were found from approximately $40 \%$ of the bombarded immature embryos or some $20 \%$ of the embryogenic calli. Since the cell clusters were separated at an early stage, fusion or co-mingling of cell clusters from different transformation events on the same piece of explant was prevented. Therefore, not only was the transformation efficiency substantially increased from that previously reported (Christou et al. 1991), but also the possibility of regenerating chimeric plants from fusion of distinct transformation events was greatly reduced.

Table 1. Hyg ${ }^{r}$ cell clusters obtained from transformation after 2 weeks of selection on hyg B

\begin{tabular}{|c|c|c|c|c|}
\hline Variety & Explant & $\begin{array}{c}\text { No. of } \\
\text { explants } \\
\text { bombarded }\end{array}$ & $\begin{array}{l}\text { No. of hygr } \\
\text { cell clusters } \\
\text { obtained }\end{array}$ & $\begin{array}{l}\text { Hyg }{ }^{{ }} \text {clusters } \\
\text { /explant }\end{array}$ \\
\hline $\begin{array}{l}\text { Taipei } \\
309\end{array}$ & im.e. & 34 & 57 & 1.7 \\
\hline 8706 & im.c. & 75 & 189 & 2.5 \\
\hline Tetep & im.c. & 22 & 60 & 2.7 \\
\hline 8706 & callus & 94 & 43 & 0.5 \\
\hline 77125 & callus & 160 & 57 & 0.4 \\
\hline
\end{tabular}

im. e.: immature embryo

When the explants were bombarded with tungsten particles coated with both pMON410 (or pNG3) and pAct1D, some of the hyg ${ }^{\mathrm{r}}$ cell clusters turned blue after incubation with X-Gluc, indicating that they resulted from co-transformation events (Figs. 1C, 1D, 1E). In some clusters both blue and white sectors were seen. Such clusters may originate from two different transformation events, or, from cases in which non-transgenic cells survived due to detoxification of hyg $B$ by the adjacent transformed cells (Christou et al. 1991; Fig. 1E). However, we did not see blue-white chimeric calli after growing under continuous selection. It appeared that the surrounding non-transformed cells were gradually degenerated under selection pressure.

\section{Yield of hyg ${ }^{r}$ callus lines and regeneration of hyg ${ }^{r}$ plants}

When the hyg ${ }^{\mathrm{r}}$ cell clusters were carefully excised under a dissection microscope, a brown scar could usually be seen at the base of the clusters, especially when immature embryos were used as target tissues. This is the junction between the cell cluster and the "parental" explant tissue, and can be generally used as a criterion for identifying individually originated cell clusters. The clusters usually grew well when transferred to medium without hyg B, whereas $45-65 \%$ survived when grown on medium containing $30 \mathrm{mg} / \mathrm{l}$ of hyg $B$ (Table 2). After further selection at $50 \mathrm{mg} / \mathrm{l}$ of hyg $B$, the cell clusters grew to form hyg ${ }^{\mathrm{T}}$ callus lines (Fig. 2A, left).

When the size of the hyg ${ }^{\mathrm{r}}$ calli reached approximately 5 $\mathrm{mm}$ in diameter, they were transferred to regeneration medium containing $50 \mathrm{mg} / \mathrm{l}$ of hyg $\mathrm{B}$. We did not observe detrimental effects by addition of hyg $B$ to the regeneration medium (Fig. 2A, right). Usually 1-5 plantlets (or plantlet clusters) were obtained from a piece of hyg ${ }^{\mathrm{I}}$ callus; this formed a plant line. The regenerated plantlets were then transferred to plantlet growth medium that also contained $50 \mathrm{mg} / \mathrm{l}$ of hyg $\mathrm{B}$. We found that selection at the plantlet growth stage was quite efficient: the control plantlets (i.e. those regenerated from non-transformed calli) did not grow and finally died whereas the putative transformants grew normally (Fig. 2B). In PCR assays using primers derived from the HPH coding sequence, 30 out of 35 plants that survived selection showed the expected size of the amplified DNA fragment, indicating that at least $85 \%$ of the hyg $r$ plants are true transgenic plants. Figure 5 shows the result of PCR assay of eight putative transgenic plants: seven of them have the expected size of the amplified DNA.

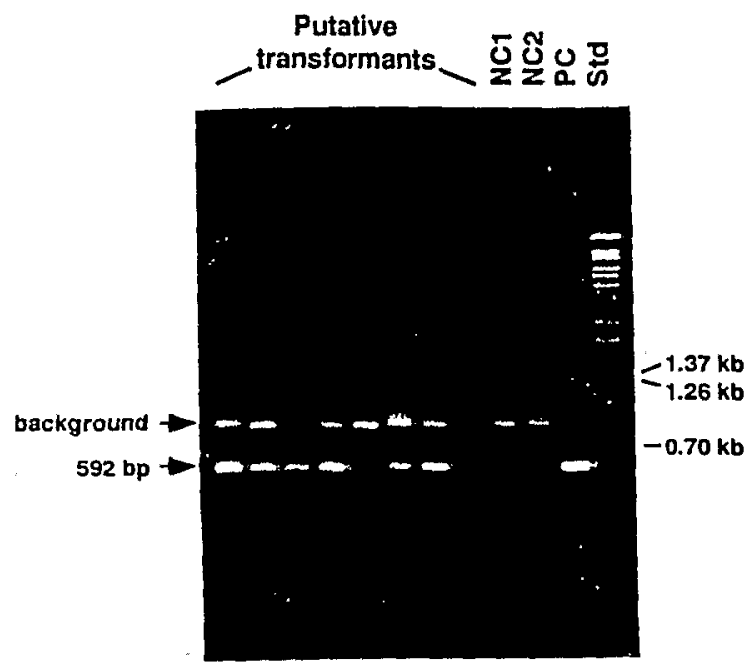

Figure 5. Agarose gel electrophoresis of PCR-amplified DNA from putatively transformed plants. Each lane represents an individual plant. NC1 and NC2: non-transformed Taipei 309 and 77125 plants, respectively. PC: $1 \mathrm{ng}$ of the plasmid pMON410 was used in the reaction. The $592 \mathrm{bp}$ fragment represents the amplified fragment of the HPH genc. The band above is apparently a specific sequence found in all plant DNA samples tested and is not related to the transformation events.

Table 2. Survival and regeneration of hyg $\mathrm{r}$ cell clusters

\begin{tabular}{lccccc}
\hline \multirow{2}{*}{ Variety } & \multirow{2}{*}{ Explant } & $\mathrm{Hyg}^{\mathrm{r}}$ cell & $\mathrm{Hyg}^{\mathrm{r}}$ callus & \multicolumn{2}{c}{$\mathrm{Hyg}^{\mathrm{r}}$ plant lines } \\
clusters & lincs & No. & $\%$ \\
\hline Taipei & im.e. & 39 & 18 & 10 & 25.6 \\
309 & im.e. & 87 & 52 & 27 & 31.0 \\
8706 & callus & 26 & 17 & 11 & 42.3 \\
\hline
\end{tabular}

im.e.: immature embryo

Table 2 reveals the results of selection and plant regeneration after bombardment of two rice varieties. Approximately $30 \%$ of the originally separated hyg ${ }^{r}$ cell clusters were finally regenerated into plantlets. Calculations based on the data in Tables 1 and 2 indicated that, from the best responsive variety used in the experiments (line 8706), one resistant plant line was obtained from 1.3 immature embryos or from 5 pieces of embryogenic calli bombarded, which is substantially higher than that previously reported. (Christou et al. 1991).

\section{Co-transformation}

In co-transformation experiments using construcis pMON410 (containing the HPH' gene) and pAct1D (containing the GUS gene), 33 hyg $^{\mathrm{r}}$ plants were examined and 12 showed GUS activity (Fig. 3), giving a 36\% co-expression efficiency. This is substantially lower than that reported in rice protoplast co-transformation experiments (Peng et al. 1990). 


\section{Inheritance of the HPH gene}

Integration of the introduced HPH gene into the genome of transgenic rice plants was shown by Southern blot hybridization reactions of the undigested genomic DNA of the plants (Fig. 6). When the genomic DNAs were digested with either Hind III or Not I, different transformants showed various digestion patterns. Since neither of the restriction enzymes used in the experiments. has a cleavage site within the $1.8 \mathrm{~kb} \mathrm{HPH}$ gene construct, it seems that at least some lines carry multiple copies of the gene. The segregation of the hyg ${ }^{r}$ trait among offspring of the transgenic plants was demonstrated by germinating R1 seeds on medium containing $50 \mathrm{mg} / \mathrm{l}$ of hyg B (Table 3, Fig. 4). Table 3 shows $3: 1$ segregation among offspring of three transgenic plants, indicating Mendelian inheritance from a single genetic locus of a functional HPH gene.

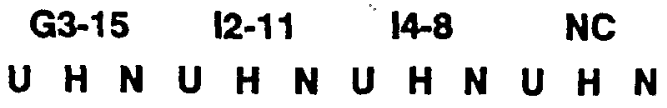

$7.2 \mathrm{~kb}$

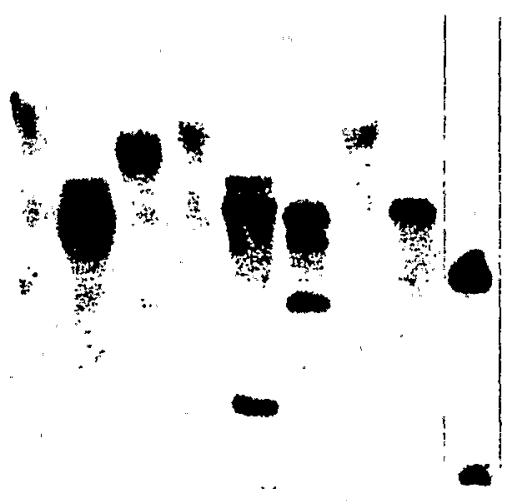

$1.3 \mathrm{~kb}$

Figure 6. Southern blot hybridization reaction of total DNA of $3 R_{0}$ trans genic rice plant lines, demonstrating integration of the HPH gene. $U$ : undigested DNA; H: DNA digested with Hind III; N: DNA digested with Not I. NC: Taipei 309. The low intensity band of undigested genomic DNA may have resulted from inefficient transfer of high molecular weight DNA.

\section{Concluding remarks}

The generation and maintenance of embryogenic suspension cell cultures for rice transformation experiments are labor intensive and generally genotype-dependent. The practice of using immature embryos as target tissue for rice transformation by particle bombardment, as reported by Christou et al. (1991), made rice transformation independent of the suspension cell cultures and simplified the procedure. In our experiments, we found that by excising hyg ${ }^{r}$ cell clusters at an early stage from tissues bombarded with HPH gene (two weeks after applying hyg B selection), and by continuous selection during regeneration as well as plantlet growth, the transformation and selection efficiencies were substantially improved. Figure 7 outlines the procedure we used in our studies. By employing this proce dure, we have been able to develop several hundred trans- genic plants which can grow normally on medium containing $50 \mathrm{mg} / \mathrm{l}$ of hyg $B$.

Table 3. Inheritance of the hyg ${ }^{r}$ trait in $R_{1}$ generation

\begin{tabular}{ccccc}
\hline $\begin{array}{c}\text { Transgenic } \\
\text { rice line }\end{array}$ & $\begin{array}{c}\text { Ri seeds } \\
\text { germinated }\end{array}$ & $\begin{array}{c}\text { Well-grown } \\
\text { seedlings }\end{array}$ & $\begin{array}{c}\text { Dead } \\
\text { seedlings }\end{array}$ & $\chi^{2}$ \\
\hline $\begin{array}{c}\text { I4-29 } \\
\text { (Taipei 309) }\end{array}$ & 40 & 31 & 9 & 0.133 \\
$\begin{array}{c}\text { K1-1-45a } \\
(8706)\end{array}$ & 48 & 36 & 12 & - \\
$\begin{array}{l}\text { M7-1a } \\
\text { (TN1) }\end{array}$ & 48 & 37 & 11 & 0.111 \\
\hline
\end{tabular}

Data were collected 2 weeks after the seeds were germinated on hyg $\mathrm{B}(50 \mathrm{mg} / \mathrm{l})$-containing medium. All control seedlings were dead. $\chi^{2}$ tests indicate good agreement with segregation ratios of 3:1.

\section{Bombard explants with HPH gene}

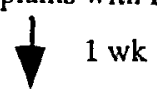

Transfer explants to selection medium (hyg B, $30 \mathrm{mg} / \mathrm{l}$ )

$$
\downarrow 2-3 \text { wks }
$$

Excise resistant cell clusters, place on selection medium (hyg $B, 30 \mathrm{mg} / \mathrm{l}$ )

$$
\downarrow^{2-3} \text { wks }
$$

Transfer resistant calli to selection medium (hyg B, $50 \mathrm{mg} / \mathrm{l}$ )

$$
\text { I 2-3 wks }
$$

Transfer resistant calli to selection medium (hyg B, $50 \mathrm{mg} / \mathrm{l}$ )

$$
\text { 1. } 2-3 \mathrm{wks}
$$

Transfer resistant calli to regeneration medium (hyg B, $50 \mathrm{mg} /$ )

$$
1 \text { 3-4 wks. }
$$

Transfer resistant plantlets to plantlet growth medium (hyg $B, 50 \mathrm{mg} /$ )

$$
\text { Transplant to soil }
$$

Fig. 7. Outline of the rice transformation-selection procedure

Our work also demonstrates that embryogenic calli can be used for rice transformation by the biolistic method. Subcultured calli, or primary calli from mature seeds, do not depend on the availability of flowering plants. This advantage makes calli an alternative material for rice transformation. However, long-term subcultured calli may lose regeneration ability, or the plants regenerated from such cultures may be sterile (our unpublished data). Therefore, when using embryogenic calli for transformation, primary calli from immature or mature embryos, and short-term (no longer than 3-4 months) subcultured calli are preferred.

Although varieties of both japonica and indica rice can be transformed in our experiments, the capacity for plant regeneration is quite genotype-dependent, and is still a limiting factor especially for indica rice transformation. We are currently trying to improve the regeneration rate of indica varieties by testing various factors. 


\section{Acknowledgments}

We thank Yongrui Chen for excellent technical assistance. The authors are grateful to Dr. Shanbao Chen for rice line 77125, Dr. Ying Chen for rice line 8706, Dr. R. Wu for pAct1D, Dr. M. C. Van Montagu for pNG3, and Monsanto Company for pMON410, and to Drs. G. Toenniessen and Wenzhong Tian for helpful discussion. We also thank Sally Jo Leitner for maintenance of the transgenic plants. This work was supported in part by a grant from the Rockefeller Foundation. Other supports were provided to $\mathrm{ADK}$ and $\mathrm{CF}$ by ORSTOM, a French public research organization. LL was a recipient of a visiting scientist fellowship from the Rockefeller Foundation.

\section{References}

Bower R, Birch RG (1992) Plant J 2: 409-416

Cao J, Zhang W, McElroy D, Wu R (1991) In: Rice Biotechnology, GS Khush, GH Toenniessen (eds), CAB International, Wallingford, UK pp $175-198$

Christou P, Ford TL, Kofron M (1991) Bio/Technology 9: 957-962

Chu CC, Wang CC, Sun CS, Hsu SC, Yin KC, Chu CY, Bi FY (1975) Sci Sin 18: 659-668

Church GM, Gilbert W (1984) Proc Natl Acad Sci USA 81: 1991-1995

Datta SK, Peterhans A, Datta K, Potrykus I (1990) Bio/Technology 8: 736780

Dellaporta SL, Wood J, Hicks JB (1983) Plant Mol Bioj Rep 1(4): 19-21

Fromm, ME, Morrish F, Armstrong C, Williams R, Thomas J, Klein TM (1990) Bio/Technology 8: 833-844

Gamborg OL, Miller RA, Ojima K (1968) J Exp Res 50: 151-158

Gordon-Kamm WJ, Spencer TM, Mangano ML et al. (1990) Plant Cell 2: 603-618

Gritz L, Davies J (1983) Gene 25: 179-188

Hooykaas PJJ (1989) Plant Mol Biol 13: 327-336

Jefferson RA, Kàvanagh TA, Bcvan MW (1987) EMBO J 6: 3901-3907

Klein TM, Wolf ED, Wu R, Sanford JC (1987) Nature 327: 70-73

Klein TM, Gradzicl T, Fromm ME, Sanford JC (1988) Bio/Technology 6: 559-563

Kosugi S, Ohashi Y, Nakajima K, Arai Y (1990) Plant Sci 70: 133-140

Li Z, Burow MD, Murai N (1990) Plant Mol Biol Rep 8: 276-291

McElroy D, Zhang W, Cao J, Wu R (1990) Plant Cell 2: 163-171

McGarvey P, Kaper JM (1991) BioTechniques 11: 428-432

Murashige T, Skoog F (1962) Physiol Plant 15: 473-497

Peng J, Lyznik LA, Lce L, Hodges TK (1990) Plant Cell Rep 9: 168-172

Peng J, Kononowicz H, Hodges TK (1992) Theor Appl Genet 83: 855-863
Rogers SG, Klee HJ, Horsch RB, Fraley RT (1987) In: Methods in Enzymology, vol 153, R Wu, L Grossman (eds), Academic Press, San Diego, pp 253-277

Sambrook J, Fritsch EF, Maniatis T (1989) Molecular Cloning, A Laboratory Manual, Cold Spring Harbor Laboratory Press, Cold Spring Hasbor, New York

Shimamoto K, Terada R, Izawa T, Fujimoto H (1989) Nature 338: 274 276

Thompson JA, Abdullah R, Cocking EC (1986) Plant Sci 47: 123-134

Toriyama K, Arimoto Y, Uchimiya H, Hinata K (1988) Bio/Technology 6: 1072-1074

Vasil V, Castillo AM, Fromm ME, Vasil IK (1992) Bio/Technology 10: 667-674

Zhang HM, Yang H, Rech EL, Golds TJ, Davis AS, Mulligan BJ, Cocking EC, Davey MR (1988) Plant Cell Rep 7: 379-384

Zhang W, Wu R (1988) Theor Appl Genet 76: 835-840

Figures 1-4. 1. (A) GUS activity 2 days after bombardment of immature embryos with the plasmid pAct1D. (B) GUS activity $2 \mathrm{~d}$ after bombardment of embryogenic calli with the plasmid pAct1D. (C) An immature embryo bombarded with plasmids pMON410 and pAct1D $17 \mathrm{~d}$ after selection on the medium containing hyg $\mathrm{B}$. The embryo stained with $\mathrm{X}$ Gluc indicated multiple transformation events. (D) A piece of callus tissue bombarded and treated as described in (C), illustrating two hyg cell clusters which also showed GUS activity. (E) A cross section through an immature embryo bombarded and treated as described in (C), in which the central sector of the hyg ${ }^{\mathrm{r}}$ cell cluster showed GUS activity while the surrounding cells did not. The scars caused by bombardment are illustrated as well. See text for details. 2. (A) Left: callus lines formed from hyg ${ }^{\mathrm{r}}$ cell clusters grown on medium containing $50 \mathrm{mg} / \mathrm{l}$ of hyg $\mathrm{B}$. One callus line for each grid (line 8706). Right: plantlet regeneration of $\mathrm{hyg}^{\mathrm{r}}$ calli on regeneration medium containing $50 \mathrm{mg} / \mathrm{l}$ of hyg $\mathrm{B}$. One plant line for each grid. (B) Regenerated plantlets (line 8706) from hyg ${ }^{\mathbf{r}}$ calli (right box) and non-transformed calli (left box) on medium containing $50 \mathrm{mg} / \mathrm{l}$ of hyg $\mathrm{B}$. 3. Plantlets regenerated from hyg ${ }^{r}$ calli after bombardment of immature embryos with plasmids pMON410 and pActID, stained with X-Gluc, indicating they were from co-transformation events (line 8706). 4. Seeds (R1) of transgenic rice plant line 14-6 germinated on medium containing $50 \mathrm{mg} / \mathrm{l}$ of hyg $\mathrm{B}$, indicating segregation of hyg $\mathrm{g}^{\mathrm{r}}$ among the offspring (left box). The seeds from control (non-transformed) plant were all dead 2 weeks after germination on the same medium (right box) (variety: Taipti 309 ). 
$4:$
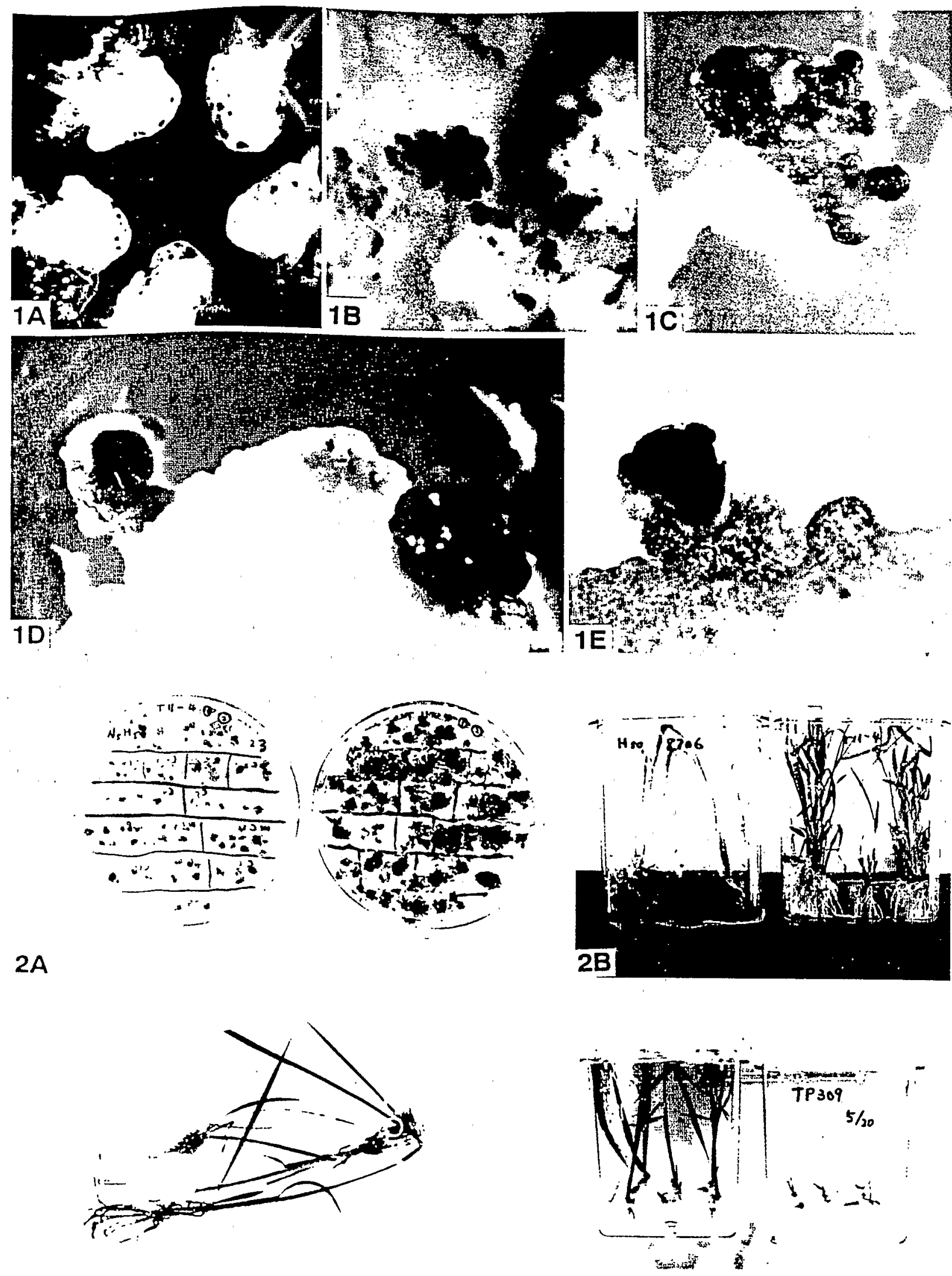